\title{
Sensitivity of Different Early Developmental Periods of Baltic Herring (Clupea harengus) to Water-accommodated Fraction of Crude Oil
}

\author{
Riikka Venesjarvi $^{1, *}$ and Juha Karjalainen ${ }^{2}$ \\ ${ }^{1}$ University of Helsinki, Fisheries and Environmental Management Group, Department of Environmental Sciences, \\ Heikinkatu 7, FIN-48100 Kotka, Finland \\ ${ }^{2}$ University of Jyvaskyla, Department of Biological and Envoronmental Science, P.O. Box.35. Fl-40014 Jyvaskyla, \\ Finland
}

\begin{abstract}
The probability for the oil accident to occur at the Gulf of Finland has been increasing last ten years and it is predicted to continue so. The risk is high based on the accident probability and the probable harm caused; some spawning areas of the Baltic herring (Clupea harengus membras) are located in the vicinity of ports and ship fairways with heavy traffic, so any oil spillage there could affect recruitment of this commercially important species. In this study, newly fertilized embryos, the older embryos and the hatched larvae of Baltic herring were exposed to water-accommodated fraction (WAF) made from crude oil. Oil exposure increased most the mortality of the hatched larvae, and larvae hatched during the exposure were more sensitive to the impacts of oil than larvae which were exposed after their hatching. The $\mathrm{LC}_{50}$ value was $16 \%$ of WAF-solution of crude oil for the exposed larvae. The most tolerant for the oil were the embryos in late embryonic stage (the $\mathrm{LC}_{50}$ was $44 \%$ of WAF-solution). During the exposure, some malformations i.e. a curving of the notochord were noticed.
\end{abstract}

Keywords: Crude oil, WAF, Baltic herring, early development, length, curving of notochord.

\section{INTRODUCTION}

The part of the Baltic Sea most heavily used by oil tankers is the Gulf of Finland and it is predicted that by 2020 the amount of oil transported will be 170 million tons according to the slow growth scenario and 200 million tons with a strong growth scenario, which correspond the increase of 13 and $34 \%$, respectively, compared to the year 2009 [1,2]. In the case of an accident, large and hazardous amounts of crude oil may be spilled into the sea. When oil is spilled, it starts to spread and mix with the water. Oil acts differently in the open sea and when it is dispersed by coastal rocks $[3,4]$. In the Gulf of Finland, some spawning areas of the Baltic herring are located in the vicinity of ports and ship fairways with heavy traffic [5], so any oil spillage there could affect recruitment of this commercially important species.

Generally, the nature and duration of impacts from an oil spill depend on several factors: most important are the amount of crude oil and its behaviour once spilled, the weather conditions and season [4]. The characteristics of crude oil also affect how it behaves once spilled [6]. The relative density describes the buoyancy of oil, distillation properties describe the ability of oil to evaporate from water, viscosity describes the resistance of flow and below the

*Address correspondence to these authors at the University of Helsinki, Fisheries and Environmental Management Group, Department of Environmental Sciences, Heikinkatu 7, FI-48100 Kotka, Finland;

Tel: +358504150609; E-mail: riikka.venesjarvi@helsinki.fi melting point the oil solidifies [4]. Most of the weathering processes undergo within the first 30 hours. The most visible process is the spreading over the sea surface, which is affected by weather conditions e.g. streams, wind speed and currents [6]. The dominant factor removing oil from the sea environment is evaporation $[4,6]$. On the other hand, immediately after the spill the oil can multiply its volume three times by emulsification. After the first 24 hours oil starts to sediment [4]. Altogether the oil can affect directly or indirectly the living environment of the Baltic herring for a year [4]. The medium-weight components of crude oils pose the greatest environmental risks to organisms because those are more persistent and the polycyclic aromatic hydrocarbons (PAHs) have high toxicities [6]. PAHs are causing the most concern of chemical components of oil products regarding environmental risk [7-9]. It is noteworthy that PAHs are more persistent in arctic waters [10].

The early development of fish larvae is affected by crude oil in many ways. Crude oil exposure affects the length of hatched larvae of the Baltic herring (Clupea harengus) $[11,12]$. Brown et al. [13] also reported that the weight of Pacific herring (Clupea pallasi) larvae is smaller after oil exposure. A curving of the notochord and other malformations are commonly observed after crude oil exposure [7,8,11-14]. Sublethal effects caused by embryonic PAH exposures include e.g. edemas, changes in progeny, neuronal cell death, failed inflation of the swim bladder and anemia [14-16]. Alkylphenanthrenes are PAH constituents of crude oil and have been implicated in the toxicity of crude oil es- 
pecially to the early states [17]. PAH toxicity is linked to aryl hydrocarbon receptor (AhR) and alkylphenanthrenes such as retene are shown to produce AhR-dependent cardiac toxicity [17]. Crude oil exposure has been reported to shorten the hatching time of Pacific herring $[9,13]$, while according to Lindén [11] the mortality of Baltic herring during oil exposure is highest immediately after hatching. On the other hand, Brown et al. [13] did not observe increased egg mortality during embryonic incubation after exposure of Pacific herring to crude oil when eggs were collected from oiled sites after the Exxon Valdez oil spill and then hatched in the laboratory.

Our objectives were to study how exposure to crude oil affects newly fertilized embryos, embryos in the late stages of development and hatched larvae of the Baltic herring. The exposures were carried out at temperatures and exposure levels of the water-accommodated fraction of crude oil (three exposure levels and control) that correspond the predicted field conditions after oil spill during early development of herring in spring [5].

\section{MATERIALS AND METHODS}

Mature females and males of Baltic herring were caught on 4 May 2007 by fyke nets from an area in front of the town of Hamina on the Eastern Gulf of Finland. The fish were packed in ice and transported within six hours to the University of Jyväskylä where eggs from one ripe female were stripped and fertilized by the milt from five males by the dry method.

From 100 to 150 eggs were deposited on a glass slide and fertilized by $2 \mathrm{~mL}$ of milt at $10^{\circ} \mathrm{C}$. Four slides were first placed in a Petri dish (diameter $15 \mathrm{~cm}$ ) with $5 \%$ artificial seawater (Instant Ocean, Spectrum Brands Inc.), the Petri dishes were shaken gently for five minutes until the water had turned milk white and were then flushed gently with clean seawater. After fertilization, slides were selected randomly and a fixed number was transferred to each of the experimental glass dishes (16 slides for early embryo exposures). A further 30 slides were transferred to two aerated hatching containers in order to collect newly hatched larvae for the following exposure experiments.

Three oil exposures for the herring eggs and larvae at different developmental stages were performed. The first exposure started immediately after fertilization, while the second was made with the embryos in the late embryonic stage and the third with hatched larvae. All embryos and larvae were exposed only once in the experimental exposures (no repeated exposures). Three treatment levels were used: 5, 40 and $80 \%$ WAF-solution (water-accommodated fraction, 29) of crude oil. A control exposure was carried out in clean artificial seawater. WAF-solution was made from Primorsk Export Blend -crude oil (which is a blend from Russian crude oils) and artificial seawater. The ratio for crude oil and seawater was 1:9. The solution was made in a $1 \mathrm{~L}$ glass bottle which was shaken for 24 hours in a mixer at $100 \mathrm{rpm}$. The oil phase was then pipetted from the bottle and the remaining water fraction was used to make the dilutions needed in the experiments. The dilutions were made in $1 \mathrm{~L}$ glass bottles.
All exposures were made in $1.5 \mathrm{~L}$ glass dishes with $0.5 \mathrm{~L}$ of water. The first exposure started after fertilization when the eggs were attached to the slides in the glass dishes. In every exposure there were 16 test dishes, four controls and four of each of the three treatments. The exposure lasted 96 hours and every 24 hours 0.25 litres of water were taken out from the test dishes and replaced by new test water. The light rhythm was adjusted to 14:10 hours (Light:Dark) per day. After the exposure period, the numbers of living and dead eggs were counted and all visible abnormalities were recorded. The fertilized eggs did not reach the late embryonic stage corresponding the eyed state during the first exposure.

The second exposure started when $50 \%$ of embryos in the hatching containers had reached the eyed stage. 16 randomly selected slides were transferred to the exposure and control dishes. The test protocol was similar to that in the early embryonic exposure. Again, the exposure lasted 96 hours and the test water was changed every 24 hours. During the exposure part of the embryos hatched. From every dish the number of eggs and hatched larvae and their mortality were recorded. Visible abnormalities, such as curving the notochord, were also recorded.

The third exposure started when $50 \%$ of embryos in the hatching container had hatched. 30 newly hatched larvae were added by Pasteur-pipette with cutted suction tip to each test dish with the solutions of $0,5,40$ and $80 \%$ WAF. To oxygenate the water the test solution was not changed but new test solution was added so the larvae would not be removed from the tank by accident. Every 24 hours $0.125 \mathrm{~L}$ of new test solution was added to dishes so that by the end of the exposure every tank contained $1 \mathrm{~L}$ of test solution. The exposure lasted 96 hours. After exposure the mortality of larvae and visible abnormalities were recorded. All treatments were made at $8-11^{\circ} \mathrm{C}$ and all added water was cooled to $10^{\circ} \mathrm{C}$. During all exposures the temperature and $\mathrm{pH}$ of water were measured from control tanks daily. The water temperature was (mean+/-SD) 11.1+/-0.5, 10.9+/-0.6, $10.9+/-0.6$ and $\mathrm{pH} 8.0+/-0.1,8.0+/-0.1,8.1+/-0.1$ in the exposures 1,2 and 3 , respectively.

The differences in the percentage mortality of embryos and larvae between treatments were tested with one- and two-way ANOVA. The percentages were $\arcsin \sqrt{ }{ }_{\mathrm{x}}$-transformated before testing. The combined effect of oil exposure and developmental stage was also tested. In order to determine $\mathrm{LC}_{50}$-values (lethal concentration where $50 \%$ of embryos or larvae died) for all exposures probit analyses [18] were carried out. Control groups were included in the analysis.

\section{RESULTS}

The WAF exposure during early development increased the mortality of Baltic herring (2-way ANOVA with WAF level and developmental stage as the independent variables: $\left.\mathrm{F}_{3,180}=49.288 ; \mathrm{p}<0.001\right)$. When the WAF level was $80 \%$ only $10 \%$ of fertilized eggs survived during 96 hours exposure (Fig. 2). The developmental stage also affected the mortality significantly $\left(\mathrm{F}_{2,180}=36.601 ; \mathrm{p}<0.001\right)$, since some of the stages were more sensitive. The WAF level and the developmental stage also had a combined effect on the mortality of Baltic herring $\left(\mathrm{F}_{6,180}=11.293 ; \mathrm{p}<0.001\right)$. 
Exposure immediately after fertilization significantly affected the mortality of eggs (1-way ANOVA: $\mathrm{F}_{3,60}=$ 171.722; $\mathrm{p}<0.001)$. There was no difference between the control and $5 \%$ WAF level, but the mortality increased at the higher levels (Fig. 1). In the first exposures, the $\mathrm{LC}_{50}$ was $44 \%$ of WAF-solution. The mortality of eggs in the control treatment was $13 \%$.
Exposure in the late embryonic stage (Exposure 2) did not affect the mortality of Baltic herring (ANOVA: $\mathrm{F}_{3,60}=$ 3.232; $p>0.05$ ) (Fig. 2). During this exposure some of the larvae hatched and the mortality of embryos in eggs and of hatched larvae differed. The mortality of embryos and hatched larvae was therefore examined separately (Fig. 2). The WAF exposure did not affect the mortality of embryos in the late stages of development (ANOVA: $F_{3,60}=3.249 ; p$

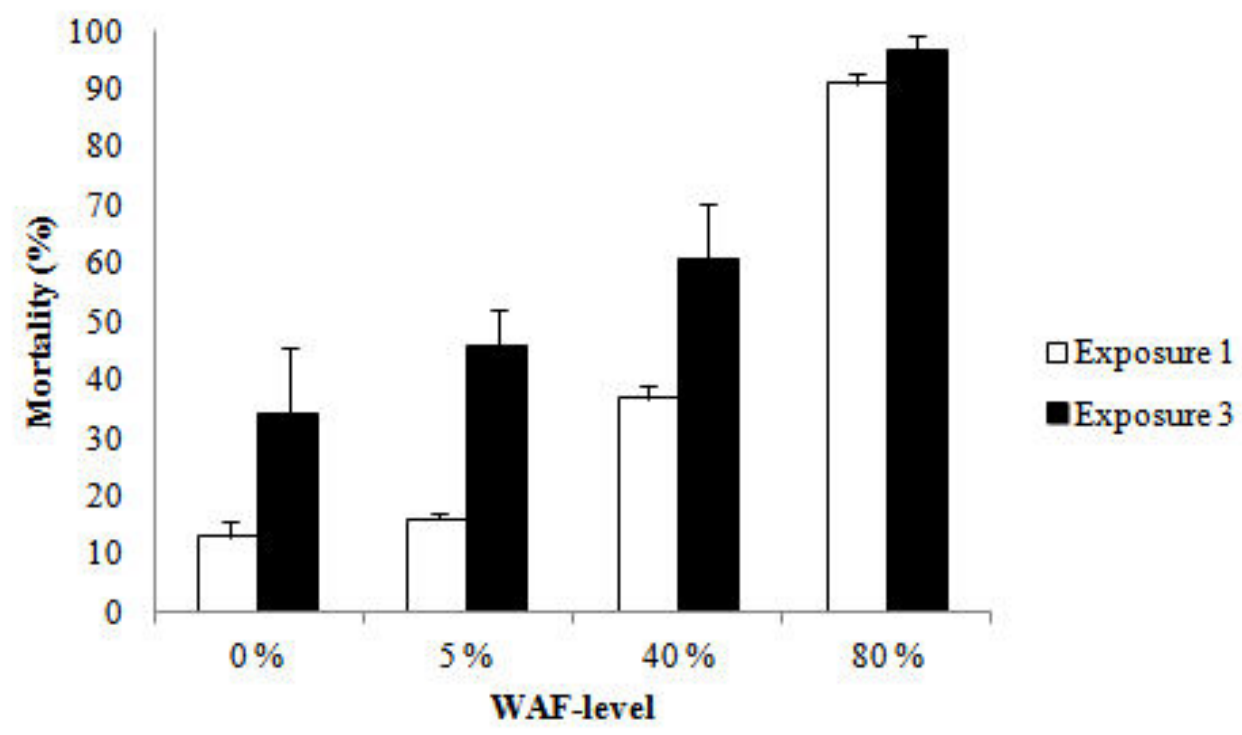

Fig. (1). The percentage mortality (\%) of Baltic herring including embryos and larvae (Exposure $1=$ from fertilization to eyed stage and Exposure 3 = hatched larvae with yolk sac) during 96 hours exposure in the 0, 5, 40 and $80 \%$ WAF-solutions of crude oil. The vertical lines show the standard errors.

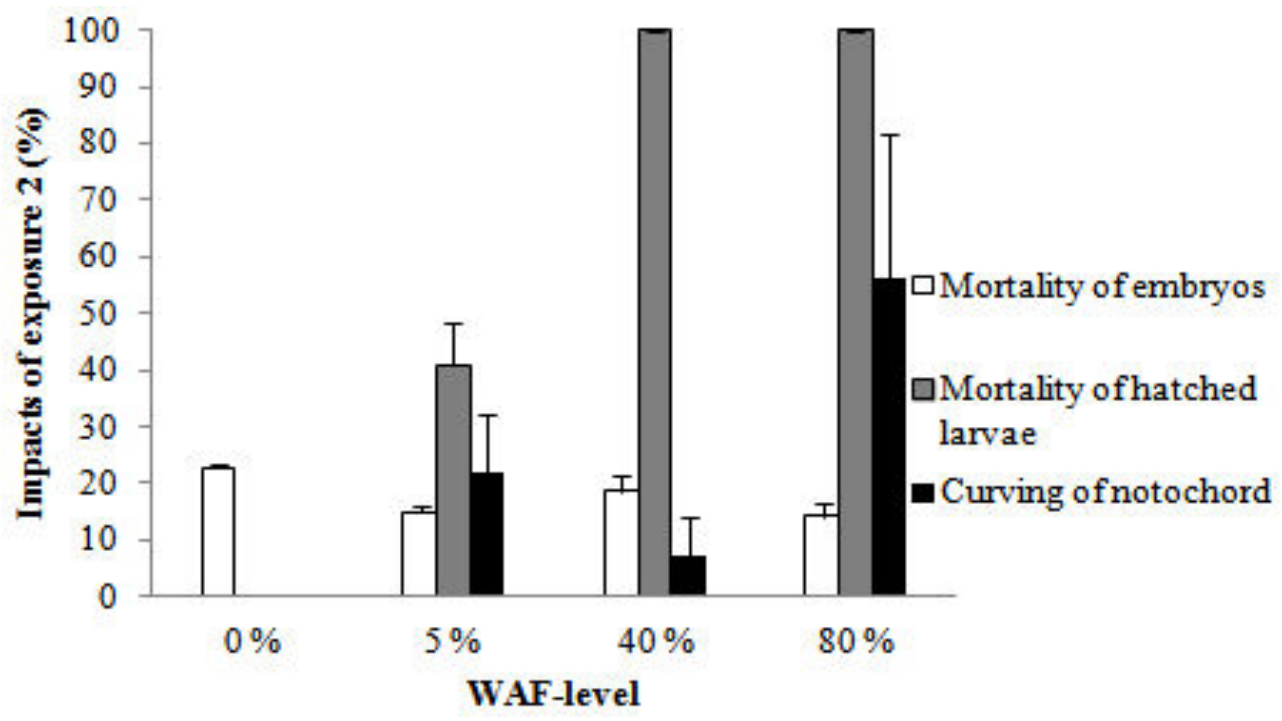

Fig. (2). The figure shows the differences between embryonic mortality and mortality of the hatched larvae when the exposure occurred during eyed stage. The percentage mortality (\%) of Baltic herring embryos and hatched larvae after 96 hours exposure (Exposure $2=$ from eyed stage to hatching) in 0,5, 40 and $80 \% \mathrm{WAF}$-solutions of crude oil. The figure also includes the proportion of hatched Baltic herring larvae with a visibly curved notochord after 96 hours exposure (Exposure 2 = from eyed stage to hatching) in the $0,5,40$ and $80 \%$ WAFsolution of crude oil. The vertical lines show the standard errors. 
$>0.05)$ but did affect the mortality of newly hatched larvae (ANOVA: $\mathrm{F}_{3,60}=393.598 ; \mathrm{p}<0.001$ ). All hatched larvae died when the levels of WAF-solution were 40 or $80 \%$. The hatched larvae also had malformations such as notochord curving: in the highest WAF level over $50 \%$ of larvae had several curves in all the way of a notochord. The curving was only noticed in Exposure 2 (Fig. 2). No other malformations were considered.

In Exposure 3, oil exposure significantly affected the mortality of larvae (ANOVA: $F_{3,60}=14.613$; $p<0.001$ ). The mortality increased towards higher WAF levels (Fig. 1) and in general was higher than in Exposures 1 and 2: the $\mathrm{LC}_{50}$ was $16 \%$ of WAF-solution of crude oil. The average larval mortality (in the control treatment (34\%) was higher in Exposure 3 than in the previous Exposures.

\section{DISCUSSION AND CONCLUSION}

Newly fertilized eggs (from fertilization to eyed stage) were more sensitive to WAF than eggs in the late embryonic stage (from eyed stage to hatching). According to Rice [18] the tolerance of eggs to the effects of oil increases as their development proceeds. Components of oil can penetrate the plasma membrane of eggs and this penetration ability is highest after fertilization [19]. During Exposure 2 (from eyed stage to hatching) low mortality was observed before hatchings but the WAF exposure caused very high mortality among the hatched larvae; in fact, newly hatched larvae were the stage most sensitive to crude oil exposure in all WAF levels. Either even short exposure after hatching was harmful or, perhaps more likely, some embryonic malformations were not expressed until just after hatching. Thus, embryonic disturbances prior to hatching may be difficult to evaluate if damaged eggs appear viable and hatch successfully. The mortality of exposed embryos was low in control treatments thus it may be assumed that the test protocol in Exposure 1 and 2 did not harm the embryos. The control group mortality was higher in Exposure 3, hence the handling of larvae may have been harmful.

Larvae hatched during the exposure (Exposure 2) were more sensitive to the impacts of oil than larvae which were exposed after their hatching (Exposure 3). Moreover, curving of the notochord was noticed only from larvae hatched during the exposure. The curving of the notochord weakens the swimming ability of the larvae [19] which affects their subsequent survival $[11,20]$. Our observations are thus consistent with previous studies [12,21]. According to McIntosh et al. [22] newly fertilized embryos are more sensitive than the newly hatched embryos, which is the opposite of our results. However, it is noteworthy that in this previous study crude oil was dispersed before creating the WAF solution.

According to Rice [17], fish in the early stages of development are particularly sensitive to the impacts of oil because they do not yet have the necessary structures to process detrimental substances. In larval stage organs are still undeveloped and the accumulation routes of the substances differ from those in adult fish [23]. Levels of oil that can be resisted by embryos protected by a chorion can often be lethal to the larvae [19,24], since fish larvae accumulate harmful substances intensively through their skin [19]. Some species (such as cod and salmon) develop tolerance to oil toxicity toward the end of embryonic development but tolerance decreases again when the larvae hatch and continues to fall as the yolk is used $[25,26]$.

In this study, the impacts of crude oil depended on the crude oil level and the developmental stage of Baltic herring. In all developmental periods tested here, the highest ( $80 \%$ of WAF-solution) WAF level caused the highest mortality. No great differences in mortality were evident between the control level and $5 \%$ level. Generally fish kills after oil spills are not documented because toxic concentrations are seldom achieved in marine environments and adult fish are able to avoid surface contamination [18]. Eggs and larvae of Baltic herring cannot avoid oil and most likely will come into contact with it [18]. However, the mortality in the laboratory experiments may not be consistent with the oil-spill-caused mortality in nature since the weathered crude oil is phototoxic i.e. ultraviolet radiation (UV) can be significant and causative factor of the mortality in early stages [27].

Malformations or aberrations in development in many species are observed in concentrations less than $1 \mathrm{ppm}$ of PAHs [18,21]. After $12 \mathrm{~h}$ exposure in WAF-solution made from similar crude oil as used in this study and sea water in 1:10 ratio, the concentration of PAHs was $2.6 \mathrm{ppm}$ [11]. The concentration used by Lindén [11] was similar to the $80 \%$ WAF-concentration used in our study. Also the temperature of $9^{\circ} \mathrm{C}$ used by Lindén [11] was similar to the temperature in our study. Low temperature may affect the ability of fish to metabolise or excrete PAHs and their metabolites, and low temperatures usually increase the retention [18]. Also the exposure of fish to PAHs is greater in low salinity as in our study compared to full salinity (i.e. 32\%o) [28]. The salinity level used in this study corresponds to the average level in the GOF [29]. In nature, the levels of $624+/-0.63 \mathrm{ppm}$ were observed in open water in Prince William Sound following the Exxon Valdez oil spill (EVOS) [21]. However, the PAHs can accumulate in the tissues of aquatic organisms and the concentration of PAHs may be higher than in water [30]. When embryos were exposed to the similar concentration of PAHs as in EVOS, after 96 hours the highest total concentration of PAHs in embryos was $7.45 \mathrm{mg} / \mathrm{kg}$. Unfortunately, the PAH composition of WAF used in our study, the stability of WAF over time and the concentrations of PAH analytes in the exposures were not determined.

Altogether, our results indicated that WAF of crude oil at the environmentally realistic concentrations may increase the mortality of embryos and larvae of Baltic herring considerably and thus, endanger the reproduction of local populations of herring and other fishes. However, the results of this study cannot be directly compared to other studies because of the WAF dilution chosen; in our study high concentrations were used (1:9 dilution) compared to e.g. the one used by Couillard et al. [31] (1:1000 dilution). On the other hand, toxic effects of PAHs may not manifest until long after exposure and thus, habitat damage resulting from oil contamination is underestimated by acute toxicity assays [32]. Compounds that can penetrate the chorion and are present in crude oil but not in WAF, act synergistically which increases the toxic effects [20, 23]. Enviromental risk of oil cannot be linked exclusively to PAHs but also to other compounds capable of 
entering into organisms [20]. Our findings highlight again importance of protection of fish natal and rearing habitats.

Studies also indicate a need for risk assessment modelling in decision making [33]. On the contrary to previous assumption when the impact of oil on populations derives from acute mortality, chronic exposures at sublethal levels have continued to affect wildlife causing postponed recovery [34]. In addition to the investments done in the in-situ oil combating, the preventive actions are also required to minimize the unpredictable and long-term consequences.

\section{CONFLICT OF INTEREST}

The authors confirm that this article content has no conflicts of interest.

\section{ACKNOWLEDGEMENTS}

We thank Professor Roger Jones for comments and proofreading, Dr. Tiina Lecklin, Dr. Eeva Vehniäinen and Dr. Marjut Rajasilta for guidance and Hilkka-Liisa SiroMinkkinen from Neste Oil Ltd. and fisherman Lauri Etholen for supplying the materials.

\section{REFERENCES}

[1] Iikkanen P, Mukula M. Costs of vessel traffic accidents. Finland: Finnish Maritime Administration Publication 2008; p 38.

[2] Brunila OP, Storgård J. Oil transportation in the Gulf of Finland in 2020 and 2030. Turku: Publications from the Centre for Maritime Studies University of Turku, 2012; p 72.

[3] Albers P. Petroleum and individual polycyclic aromatic hydrocarbons. In: Hoffman D, Rattner B, Burton G, Cains J, Eds. Handbook of Ecotoxicology. London: CRC Press, 2003; pp. 341-71.

[4] ITOPF. International Tanker Owners Pollution Federation Limited. Fate of marine oil spills. Technical Information paper No. 11. London: ITOPE 2002; pp. 11.

[5] Oulasvirta P, Rissanen J, Parmanne R. Spawning of Baltic herring (Clupea harengus L.) in the western part of the Gulf of Finland. Finn Fish Res 1985; 5: 41-54.

[6] Michel J. Oil behavior and toxicity. In: Hayes M, Hoff R, Michel J, Scholz D, Shigenaka G, Eds. Introduction to coastal habitats and biological resources for spill response, report HMRAD 92-4. Seattle: Nat Ocean Atmos Administration, 1992.

[7] Kocan RM, Hose JE, Brown ED, Baker TT. Pacific herring (Clupea pallasi) embryo sensitivity to Prubhoe Bay petroleum hydrocarbons: laboratory evaluation and in situ exposure of embryos at oiled and unoiled sites in Prince William Sound. Can J Fish Aquat Sci 1996; 53: 2366-75.

[8] Incardona J, Carls M, Teraoka H, Sloan C, Collier T, Scholz N. Aryl hydrocarbon reseptor-independent toxicity of weathered crude oil during fish development. Environ Health Perspet 2005; 113: 1755-62.

[9] Carls MG, Holland L, Larsen M, Collier TK, Scholz NL, Incardona JP. Fish embryos are damaged by dissolved PAHs, not oil particles. Aquat Toxicol 2008; 88: 121-7.

[11] Lindén O. Biological effects of oil on early development of the Baltic herring Clupea harengus membras. Mar Biol 1978; 45: 27383.

[12] Urho L. Impact of an oil spill on herring stock. Proc Int Herring Symp 1990; 23-25: 569-82.

[13] Brown ED, Baker TT, Hose JE, et al. Injury to the early life history stages of Pacific herring in Prince William Sound after the Exxon Valdez oil spill. Am Fish Soc Symp 1996; 18: 448-62.
[14] Incardona J, Collier T, Scholz N. Defects in cardiac function precede morphological abnormalities in fish embryos exposed to polycyclic aromatic hydrocarbons. Toxico Appl Pharmacol 2003; 196: 191-205.

[15] Barron M, Carls M, Heintz R, Rice S. Evaluation of fish early lifestage toxicity models of chronic embryonic exposures to complex polycyclic aromatic hydrocarbon mixtures. Toxicol Sci 2004; 78: 60-7.

[16] Incardona J, Carls M, Day H, et al. Cardiac arrhytmia is the primary response of embryonic Pacific herring (Clupea pallasi) exposed to crude oil during weathering. Environ Sci Technol 2009; 43: 201-7.

[17] Scott J, Incardona J, Pelkki K, et al. AhR2-mediated, CYP1Aindependent cardiovascular toxicity in zebrafish (Danio renio) embryos to retene. Aquat Toxicol 2011; 101: 165-74.

[18] Rice S. Effects of oil on fish. In: Engelhardt FR, Ed. Petroleum Effects in the Arctic Environment. London: Elsevier Applied Science, 1985; pp 157-82.

[19] Hudd R, Urho L, Lehtonen H. Selvitys Merenkurkussa tapahtuneen $\mathrm{m} / \mathrm{s}$ Eiranöljypäästön vaikutuksista kaloihin ja kalastukseen. In: Koivulahti J, Ed. M/s Eiran öljyvahingon ympäristövaikutukset Merenkurkussa 1984. Ympäristöministeriön ympäristön- ja luonnonsuojeluosaston sarja A 1987; 61: 123-353. [In Finnish with English summary].

[20] González-Doncel M, González L, Fernández-Torija C, Navas JM, Tarazona JV. Toxic effects of an oil spill on fish early life stages may not be exclusively associated to PAHs: Studies with Prestige oil and medaka (Oryzias latipes). Aquat Toxicol 2008; 87: 280-8.

[21] Carls MG, Rice SD, Hose JE. Sensitivity of fish embryos to weathered crude oil: Part I. Low-level exposure during incubation causes malformations, genetic damage and mortality in larval Pacific herring (Clupea pallasi). Environ Toxicol Chem 1999; 18: 481-93.

[22] McIntosh S, King T, Wu D, Hodson P. Toxicity of dispersed weathered crude oil to early life stages of Atlantic herring (Clupea harengus). Environ Toxicol Chem 2010; 29: 1160-7.

[23] Kemadjou J. Effects of crude oil on zebrafish embryos. Eawag News 2008; 64: 24-6.

[24] Kime D. Endocrine distribution in fish. Massachusetts: Kluwer Academic Publishers,. 1998.

[25] Kühnhold W. The influence of crude oils on fish fry. In: Ruivo M, Ed. Marine Pollution and Sea Life. London: Fishing News Ltd, 1972; pp 315-8.

[26] Korn S, Rice S. Sensitivity to, and accumulation and depuration of aromatic petroleum components by early stages of coho salmon (Onchorhynchus kisutch). Rapp PV Reun Cons Int Explor Mer 1981; 178: 87-92.

[27] Barron M, Carls M, Short J, Rice S. Photo-enhanced toxicity of aqueous phase and chemically-dispersed weathered Alaska North Slope crude oil to Pacific herring eggs and larvae. Environ Toxicol Chem 2003; 22: 650-60.

[28] Ramachandran S, Sweezey M, Hodson P, et al. Influence of salinity and fish species on PAH uptake from dispersed crude oil. Mar Poll Bull 2006; 52: 1182-9.

[29] Alenius P, Myrberg K, Nekrasov A, The physical oceanography of the Gulf of Finland: a review. Boreal Environ Res 1998; 3: 97-25.

[30] Wang Z, Fingas M. Development of oil hydrocarbon fingerprinting and identification techniques. Mar Pollut Bull 2003; 47: 423-52.

[31] Couillard C, Lee K, Légare B, King T. Effect of dispersant on the composition of the water-accommodated fraction of crude oil and its toxicity to larval marine fish. Environ Toxicol Chem 2005; 24 : 1496-504.

[32] Short J. Long-term effects of crude oil on developing fish: Lessons from the Exxon Valdez oil spill. Energy Sources 2003; 25: 509-17.

[33] Rice S, Short J, Carls M, Moles A, Spies R. The Exxon Valdez oil spill. In: Spies R, Cooney T, Springer A, Weingartner T, Kruse G. Eds. Long-term ecological change in the northern Gulf of Alaska. Amsterdam: Elsevier Publications 2007; pp. 413-514.

[34] Peterson C, Rice S, Short J, et al. Long-Term ecosystem Response to the Exxon Valdez Oil Spill. Science 2003; 302: 2082-6. 